\title{
Students' curiosity profile in excretion system topic taught using authentic inquiry learning
}

\author{
Kasyfi Rifqi Mouromadhoni a,1, ${ }^{*}$, Sri Atun b,2, Sabar Nurohman c,3 \\ a Science Education Study Program, Postgraduate Program, Universitas Negeri Yogyakarta, Karangmalang Campus, Sleman \\ Yogyakarta 55281, Indonesia \\ Chemistry Education Study Program, Postgraduate Program, Universitas Negeri Yogyakarta, Karangmalang Campus, Sleman \\ Yogyakarta 55281, Indonesia \\ c Science Education Study Program, Faculty of Mathematics and Natural Science, Universitas Negeri Yogyakarta, Jl. Colombo No.1 \\ Yogyakarta 55281, Indonesia \\ kasyfirm@gmail.com*; 2 atun_1210@yahoo.com; ${ }^{3}$ sabarnurohman@yahoo.com \\ ${ }^{*}$ Corresponding author
}

\begin{tabular}{|c|c|}
\hline ARTICLE INFO & ABSTRACT \\
\hline $\begin{array}{l}\text { Article history } \\
\text { Received February 15, } 2019 \\
\text { Revised November 01, } 2019 \\
\text { Accepted November 19, } 2019 \\
\text { Published November 30, } 2019 \\
\text { Keywords } \\
\text { Authentic inquiry learning } \\
\text { Curiosity profile } \\
\text { Excretion system }\end{array}$ & $\begin{array}{l}\text { Curiosity is a basic important aspect encourages students in finding various information } \\
\text { which, in turn, aid them to encompass the concept learnt. This descriptive research } \\
\text { aimed at elaborating the curiosity profile of junior high school students in science } \\
\text { learning, particularly in excretion system topic who were taught using the authentic } \\
\text { inquiry learning. This research was conducted at SMP Negeri } 14 \text { Yogyakarta with } 32 \text { of } \\
\text { eight graders as the subjects. The instrument used was curiosity response } \\
\text { questionnaire. The data obtained was analyzed using percentage. The results showed } \\
\text { that the average of curiosity achievement obtained was categorized as strong }(75 \%) \text {. } \\
\text { However, the comparison of implementations between the authentic inquiry learning and } \\
\text { the other learning models are needed to get more comprehensive information. } \\
\text { This is an open access article under the CC-BY-SA license }\end{array}$ \\
\hline
\end{tabular}

\section{INTRODUCTION}

Education has an important role in building a nation (Cinnirella \& Schueler, 2018; Ramdhani, Ancok, Swasono, \& Suryanto, 2012). It is an important element for human life as it can shape superior human resources in the future (MacCann, Fogarty, \& Roberts, 2012; Pop \& Giurgiulescu, 2015). Improvement of superior human resources in the future is vital to improve the quality of education, one of which is by improving the quality of learning (Artuner, Uzun, \& Ilbars, 2012; Gajardo \& Carmenado, 2012; Reisner et al., 2017). Learning is an effort in the delivery of knowledge (Cannady, Vincent-Ruz, Chung, \& Schunn, 2019), organizing and creating a learning environment system with various methods (Falloon, 2019; Sanchez \& Weber, 2019). So that students can carry out the activities of learning effectively and efficiently and can achieve optimal learning outcomes (Gerritsen-van Leeuwenkamp, Joosten-ten Brinke, \& Kester, 2019; Zendler \& Reile, 2018). It also involves information and environment that are planned in a way that makes it easy for students to learn 
(Galeshi \& Bolin, 2019; Suprihatiningrum, 2013; Yurkofsky, Blum-Smith, \& Brennan, 2019). Moreover, learning is an activity that is carried out to initiate, facilitate, and increase the intensity and quality of learning in students (Hamalik, 2010; Kyriakides, Stylianou, \& Eliophotou Menon, 2019). It is a combination that is composed of the elements of humans, materials, facilities, equipment, and procedures that influence each other to achieve the ultimate goals (Hammami, Saeed, Mathkour, \& Arafah, 2019; Murtonen, Gruber, \& Lehtinen, 2017).

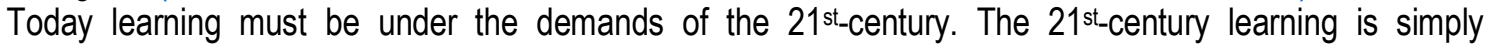

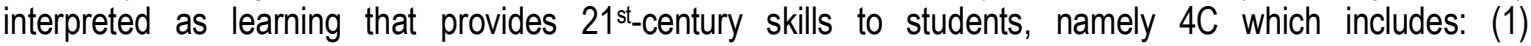
communication; (2) collaboration; (3) critical thinking and problem solving; and (4) creative and innovative (Darling-Hammond, 2006; Greenstein, 2012; Trilling \& Fadel, 2009). To realize this, the teacher as the spearhead of learning must be able to plan and implement a quality learning process (Darling-Hammond, 2006). The teacher must have good process skills in learning. Process skills can be interpreted as teacher skills in provide meaningful and enjoyable learning experiences for students (Candrasekaran, 2014; Min, Rashid, \& Nazri, 2012). It also provides student-centered learning and stimulates them to solve problems. The teacher's role is not only as a learning resource but also as a facilitator (Habók \& Nagy, 2016; Yap, Neo, \& Neo, 2016). One of these process skills is the ability of teachers to determine learning models that can accommodate the 21 st_century skills to students, for example, the application of authentic learning.

Authentic learning is a learning approach that enables students to explore, discuss, and build meaningfully concepts and relationships which involve real problems and projects that are relevant to them (Ciolan \& Ciolan, 2014; Saariaho, Toom, Soini, Pietarinen, \& Pyhältö, 2019). By providing real experiences for students and connecting them with appropriate material, authentic learning approach will make learning meaningful for students so that they are expected to be able to absorb more knowledge to the maximum (lucu \& Marin, 2014; Keinänen, Ursin, \& Nissinen, 2018; H. Wang, Sui, Luthans, Wang, \& Wu, 2014). Based on the involvement of students in authentic learning, the inquiry approach or approach through inquiry is suitable to be applied. The use of an inquiry approach that is oriented towards authentic learning guides students to find facts and concepts in science related to problems in daily life.

Based on the observation result at SMP Negeri 14 Yogyakarta, science learning was not conducted using an authentic learning approach. This is indicated by the fact that teachers were emphasized the materials by using PowerPoint. During the learning activities, there were still several students who were playing around so that not all groups could complete the tasks from the teacher and only a few students who asked questions and gave responses in the discussion process. In addition, students were reluctant to ask questions when they did not understand the learning materials. Science learning must provide a learning process that can accommodate competence (cognitive), attitude (affective), and skills (psycho-motor) of the student (Cannady et al., 2019; Trefil \& Hazen, 2016; Tursinawati, 2015). Therefore, science learning is not only limited to understanding the concepts of science but also involves other activities to optimize the attitudes and skills of students through a process of discovery to find out about science systematically (Budwig, 2015; Chiappetta \& Koballa, 2010; Timostsuk \& Jaanila, 2015). The objectives of science learning include instilling curiosity and positive attitudes towards science, the environment, technology, and society (Kumpulainen \& Rajala, 2017). Attractive and enjoyable science learning can foster student motivation and curiosity (P.-H. Wang, Wu, Yu, \& Lin, 2015). Thus, to support science learning activity, an authentic learning approach is needed (Jamalzadeh \& Shahsavar, 2015), to facilitate students in conducting an inquiry process (Gillies \& Rafter, 2019; Jerrim, Oliver, \& Sims, 2019; Jiang et al., 2018).

The observation result also indicates that the lack of curiosity in students. On the other hand, the character of students' curiosity is an important part of the character of students that need to be developed in learning (Cain, 2019; Clark, Harbaugh, \& Seider, 2019; Lamnina \& Chase, 2019; Mussel, 2013; Sakaki, Yagi, \& Murayama, 2018; Uiterwijk-Luijk, Krüger, Zijlstra, \& Volman, 2019). Curiosity can arise when looking at objects or the like (Hagtvedt, Dossinger, Harrison, \& Huang, 2019). If this attitude of curiosity can be put to good use, then humans will increasingly understand various kinds of concepts in natural phenomena (FitzGibbon, Moll, Carboni, Lee, \& Dehghani, 2019; Sakaki et al., 2018). The attitude of curiosity makes people more aware of the truth of the concept (Baniyamin \& Rashid, 2016; Mussel, 2013). Therefore, the teacher needs to apply the proper learning model to be able to trigger student curiosity so that the goal skills can be achieved, one of them using inquiry learning approach.

The inquiry learning approach is the process of defining and investigating problems, formulating hypotheses, designing experiments, finding data, and drawing conclusions of those problems (McNew-Birren \& van den Kieboom, 2017; P.-H. Wang et al., 2015). The inquiry learning provides students' understanding by developing their social skills (Wheeler, Maeng, \& Whitworth, 2013; Yudarwati, 2019). Besides, the inquiry approach specifically can be applied in laboratory activities which is the best way as a center of learning in developing the students' ability in thinking and facilitating their scientific attitudes, especially inquisitive attitude (Dobber, Zwart, Tanis, \& van Oers, 2017; Şimşek \& Kabapinar, 2010; Veloo, Perumal, \& Vikneswary, 2013). 
Based on the previous description, it can be concluded that authentic inquiry learning is a contextual learning approach based on real problems in daily life that direct students to collaborate on real activities using a variety of learning resources. Based on these problems, the researchers are concerned and motivate to study the curiosity profile of junior high school students with authentic inquiry learning in science learning. This research is a descriptive study that can later be used and aims to describe the attainment of a curious attitude by using an authentic inquiry learning approach in excretion system topic.

\section{METHOD}

This research was conducted at SMP Negeri 14 Yogyakarta in excretion system topic. The research subjects were 32 students of class VIII B. The data collection instrument used in this study was a questionnaire of curiosity attitude with 12 positive statements and 12 negative statements (related to excretion system topic) which were developed using curiosity attitude indicators as presented in Table 1. Furthermore, the correlation of the authentic inquiry learning approach stages to facilitate the attainment of a curiosity attitude is presented in Table 2. The data were collected through a questionnaire of curiosity attitude to determine the attainment of students' curiosity attitude.

Table 1. Aspects and indicators of curiosity attitude

\begin{tabular}{lll}
\hline No. & Aspects & Indicators \\
\hline 1. & Enthusiasm in finding the answers & $\begin{array}{l}\text { a. Responding quickly to the asked questions } \\
\text { b. Eagerly finding the answers from various sources }\end{array}$ \\
\hline 2. & Attention to the observed objects & $\begin{array}{l}\text { a. Focusing on the objects of observation } \\
\text { b. Concentrating on the observed objects }\end{array}$ \\
\hline 3. & Enthusiasm in the scientific process & $\begin{array}{l}\text { a. Responding quickly to the sequence of the scientific process } \\
\text { b. Showing enthusiasm in the scientific process }\end{array}$ \\
\hline 4. & Asking each activity step & a. Asking for an explanation of the activity steps that have not been understood \\
\hline
\end{tabular}

Table 2. The correlation of the authentic inquiry learning approach stages and the curiosity attitude aspects

\begin{tabular}{|c|c|c|}
\hline & Authentic inquiry learning stages & Curiosity attitude aspects \\
\hline 1. & Contextual problems & Enthusiasm in finding the answers \\
\hline 2. & Collaboration & Attention to the observed objects \\
\hline 3. & Using learning resources variation & Enthusiasm in finding the answers \\
\hline 4. & Formulating problems & Enthusiasm in finding the answers, enthusiasm to the scientific process \\
\hline 5. & Formulating hypothesis & Enthusiasm in finding the answers, enthusiasm to the scientific process \\
\hline 6. & Designing experiments & $\begin{array}{l}\text { Enthusiasm to the scientific process, asking each activity step, attention to the } \\
\text { observed objects }\end{array}$ \\
\hline 7. & Finding data & Attention to the observed objects, enthusiasm to the science process \\
\hline 8. & Drawing conclusion & Enthusiasm in finding the answers, enthusiasm to the science process \\
\hline
\end{tabular}

The attainment of curiosity attitudes was analyzed by calculating the average actual score and then converting it to a scale value of four (Widoyoko, 2013) as presented in Table 3. Furthermore, the qualitative value of the questionnaire was converted into a quantitative value questionnaire according to the provisions in Table 3.

Table 3. Provisions for converting qualitative value into quantitative value

\begin{tabular}{ccc}
\hline \multirow{2}{*}{ Answer choice } & \multicolumn{2}{c}{ Statement score } \\
\cline { 2 - 3 } & Positive & Negative \\
\hline Strongly agree & 4 & 1 \\
Agree & 3 & 2 \\
Disagree & 2 & 3 \\
Strongly disagree & 1 & 4 \\
\hline
\end{tabular}

The quantitative data that have been obtained were then analyzed by using the following steps: (1) Counting the total score of each respondent. (2) Calculating the percentage (Purwanto, 2009) of respondents' answer score by using the Equation (1). (3) Converting percentage to value by category in Table 4. The level of students' curiosity can be identified with quantitative data that have been obtained and then converted into qualitative data (interval data). The reference to converting scores into categories was adapted from Riduwan (2009). 


$$
N P=\frac{R}{S M} \times 100 \%
$$

Where NP = Percentage value; $\mathrm{R}=$ Obtained total score; and $\mathrm{SM}=$ Maximum score value .

Table 4. Provisions for converting score to category

\begin{tabular}{cc}
\hline Interval (\%) & Category \\
\hline $80-100$ & Very Strong \\
$60-80$ & Strong \\
$40-60$ & Medium \\
$20-40$ & Weak \\
$0-20$ & Very Weak \\
\hline
\end{tabular}

\section{RESULTS AND DISCUSSION}

The achievement of students' curiosity attitude is described in Table 5. Each stage of the authentic inquiry learning approach can accommodate the students' curiosity attitude aspect, will be explained in detail as follow.

Table 5. The achievement of students' curiosity attitude

\begin{tabular}{lccc}
\hline Aspects & Average score (\%) & Maximum score (\%) & Category \\
\hline Enthusiasm in finding the answers & 75 & 100 & Strong \\
Attention to each observed object & 76 & 100 & Strong \\
Enthusiasm in the scientific process & 75 & 100 & Strong \\
Asking each activity step & 74 & 100 & Strong \\
\hline Average & 75 & 100 & Strong \\
\hline
\end{tabular}

\section{Stage 1: Contextual problem}

The contextual problem stage that is related to the aspect of enthusiasm in finding the answers obtained a score of $75 \%$ with a strong category (Table 5). In line with Amar and Mullaney (2017) research which state that the existence of a problem encourages a student to be more motivated in finding the answers in the form of solutions. The use of contextual problems, related to excretion system topic, offers some challenges for students in the learning process (Sitorus \& Masrayati, 2016; Zabit, 2010). Some research also revealed that contextual problems will engage the students' attention (Bell, 2010; Chiang \& Lee, 2016) and make their curiosity straighten up (Sitorus \& Masrayati, 2016). Thus, this stage will increases students' learning activities.

\section{Stage 2: Collaboration}

Table 5 showed that the collaboration stage which is related to the aspect of attention to the object obtained a score of $76 \%$ with a strong category. This is consistent with the research results of Liao, Chen, and Shih (2019) which revealed that collaboration provides opportunities to interact in a more productive exploration process of the object of observation. The collaboration stage can provide opportunities for active learning practices (Mora, Signes-Pont, Fuster-Guilló, \& Pertegal-Felices, 2020). This stage involves the active participation of students and minimizes differences between individuals (Liao et al., 2019; Mora et al., 2020; Tissenbaum, 2020). Therefore, in this stage students' attention increases in line with the existence of collaborative discussion activities.

\section{Stage 3: Using learning resources variation}

In the third stage, using variations in learning resources, is related to the aspect of enthusiasm in finding the answers obtained a score of $75 \%$ with a strong category. The use of variations in learning resources is able to direct students in finding learning materials and facilitate students in answering questions (Huang, Han, Li, Jong, \& Tsai, 2019; Shi, 2019). At this stage, students are given the opportunity to use various learning resources related to excretion system topic to find solutions to the problems. This activity accommodates students' literacy skills to solve problems which at the same time spark their enthusiasm in finding solutions.

\section{Stage 4: Formulating problems}

Based on the result (Table 5) the formulating problems stage which is related to the aspect of enthusiasm in finding the answers and scientific process (both aspects reach strong category). At this stage, students work together in formulating problems that are in line with the main problems presented at the beginning of learning. The existence of a problem encourages a person to be more motivated in finding the solutions and it increases the students' learning activities (Amar \& Mullaney, 2017; Sitorus \& Masrayati, 2016; M. Wang, Wu, Kinshuk, 
Chen, \& Spector, 2013). Students will get used to formulating problems and finding out how to solve those problems. This is one way to build students' thinking skills and their curiosity attitude.

\section{Stage 5: Formulating hypothesis}

The next stage, formulating hypothesis, is also related to the aspect of enthusiasm in finding the answers and scientific process obtained a score of $75 \%$ with a strong category (Table 5). Students are directed to formulate provisional estimates as answers to problems that are formulated. According to Rahmaniar, Haris, and Martawijaya (2015), if students understand carefully the formulation of the problem, they can establish a basic assumption which will then be tested for truth through experimental activities. Formulating a hypothesis requires a specific, testable, and predictable statement driven by theoretical guidance and/or prior evidence (Dobber et al., 2017; Trna, Trnova, \& Sibor, 2012; P.-H. Wang et al., 2015). Therefore, students will be forced to respond actively so that an active science learning process is created.

\section{Stage 6: Designing experiments}

In the sixth stage, designing experiments, is related to the three curiosity aspect, namely asking for each activity steps (strong category), enthusiasm in the scientific process (strong category), and attention to the observed objects (strong category) as presented in Table 5. Sabirin, Muris, and Yani (2016) state that the ability to design experiments is the most important part of the science learning process. This ability consists of preparing experimental steps and preparing tools and materials, observing objects, collecting data, and interpreting data to test the hypothesis. Students are allowed to develop experimental designs to test hypotheses that have been formulated (Chu, Reynolds, Tavares, Notari, \& Lee, 2017; Tindangen, 2018; Trna et al., 2012; P.-H. Wang et al., 2015). Thus, in this stage, students can develop their curiosity, especially in asking for each activity steps, enthusiasm in the science process, and attention to the observed objects.

\section{Stage 7: Finding data}

Furthermore, finding data stage is related to the aspect of attention to the observed objects (strong category) and the aspect of enthusiasm in the scientific process (strong category). Students look for supporting evidence to answer the statement of the problem that has been made (Tindangen, 2018; Trna et al., 2012). This activity can be in the form of experiments inside and outside the laboratory. Students will collect as much data as possible to answer the problem formulation (related to excretion system topic) and test their hypotheses. According to Dobber et al. (2017) when students conduct experiments according to their own design, this will support their thinking abilities. This finding data activity can enhance the students' attention and enthusiasm in the scientific process.

\section{Stage 8: Drawing conclusions}

The final stage, drawing conclusions, is related to the aspect of enthusiasm in searching for answers and the scientific process which both categorized as a strong category. Students are allowed to explain the evidence gathered and connect the explanation with knowledge obtained from the experimental process (Dobber et al., 2017; Jiang et al., 2018; Trna et al., 2012; P.-H. Wang et al., 2015). This is in line with the research result of Astiani, Martawijaya, and Hustim (2015) which showed that the ability to conclude is the most important part of the learning process of science. As with the ability to conclude, the students will be able to understand better the essence of the problems in the science learning process and be able to interpret observation data correctly.

Based on the research result, it revealed that the score achievement of all aspects of students' curiosity attitudes results in an average score of $75 \%$ with a strong category. This shows that science learning with an authentic inquiry learning approach allows students to hone the students' ability in building new knowledge and developing scientific attitudes, especially the curiosity attitude based on real experience that they have done. the authentic inquiry leaming approach facilitates students to explore, discuss, and build meaningfully concepts and relationships which involve real problems and projects that are relevant to them (Ciolan \& Ciolan, 2014; Dobber et al., 2017; Saariaho et al., 2019; Şimşek \& Kabapinar, 2010; Veloo et al., 2013).

In addition, practicum activities become the best way as a center of learning in developing the ability and experience in thinking and facilitating students' scientific attitudes, especially the curiosity attitude (Lamnina \& Chase, 2019; Uiterwijk-Luijk et al., 2019). This is also confirmed by Cain (2019) and Clark et al. (2019) which states that the students' curiosity attitude is an important part of their characters that need to be developed during the learning process. The curiosity attitude can arise when observing the objects or the like. If this curiosity attitude can be put to good use, then humans will increasingly understand various kinds of concepts in natural phenomena (FitzGibbon et al., 2019; Hagtvedt et al., 2019; Sakaki et al., 2018). The curiosity attitude makes people more aware of the truth of the scientific concept (Baniyamin \& Rashid, 2016; Mussel, 2013). The 
results of this study indicate that authentic inquiry learning has a significant effect on student curiosity. However, the comparison of implementations between the authentic inquiry learning and the other learning models are needed to get more comprehensive information.

\section{CONCLUSION}

Based on the data description and discussion, it can be concluded that the achievement of the curiosity attitude results averages obtained a score of $75 \%$ with a strong category. Curiosity can be developed through science learning with an authentic inquiry learning approach. Based on the discussion in this research, it is suggested that the observation sheet is necessary to be used in data collection and also the questionnaire before and after learning. Comparative classes with other approaches are also needed to determine the significance of the research results obtained.

\section{REFERENCES}

Amar, A. D., \& Mullaney, K. (2017). Employee ability to innovate: How can organizations recognize it. In Procedia Computer Science (Vol. 122, pp. 494-501). Elsevier B.V. doi: https://doi.org/10.1016/j.procs. 2017.11.398

Artuner, G., Uzun, F., \& llbars, Z. (2012). Works carried out by higher education institutions for academic evaluations and quality improvement studies. Procedia - Social and Behavioral Sciences, 62, 12551259. doi: https://doi.org/10.1016/j.sbspro.2012.09.214

Astiani, A., Martawijaya, M. A., \& Hustim, R. (2015). Kemampuan menarik kesimpulan berdasarkan tabel dan grafik fisika pada peserta didik Kelas X(MIA) SMA Barrang Lompo. Jurnal Pendidikan Fisika, 3(2), 166175. doi: https://doi.org/10.26618/jpf.v3i2.264

Baniyamin, N., \& Rashid, M. M. (2016). Understanding science centre engagement in nurturing visitor interest and curiosity. Procedia - Social and Behavioral Sciences, 222, 235-243. doi: https://doi.org/10.1016/j. sbspro.2016.05.152

Bell, S. (2010). Project-based learning for the 21st century: Skills for the future. The Clearing House: $A$ Journal of Educational Strategies, Issues and Ideas, 83(2), 39-43. doi: https://doi.org/10.1080/00098 650903505415

Budwig, N. (2015). Concepts and tools from the learning sciences for linking research, teaching and practice around sustainability issues. Current Opinion in Environmental Sustainability, 16, 99-104. doi: https:// doi.org/10.1016/j.cosust.2015.08.003

Cain, J. (2019). We should pay more attention to student curiosity. Currents in Pharmacy Teaching and Learning, 11(7), 651-654. doi: https://doi.org/10.1016/j.cptl.2019.03.001

Candrasekaran, S. (2014). Developing scientific attitude, critical thinking and creative intelligence of higher secondary school biology students by applying synectics techniques. International Journal of Humanities and Social Science Invention, 3(6), 1-8. Retrieved from http://www.ijhssi.org/papers/v3 (6)/Version-2/A03620108.pdf

Cannady, M. A., Vincent-Ruz, P., Chung, J. M., \& Schunn, C. D. (2019). Scientific sensemaking supports science content learning across disciplines and instructional contexts. Contemporary Educational Psychology, 59, 101802. doi: https://doi.org/10.1016/j.cedpsych.2019.101802

Chiang, C. L., \& Lee, H. (2016). The effect of project-based learning on learning motivation and problemsolving ability of vocational high school students. International Journal of Information and Education Technology, 6(9), 709-712. doi: https://doi.org/10.7763/IJIET.2016.V6.779

Chiappetta, E. L., \& Koballa, T. R. (2010). Science instruction in the middle and secondary schools: Developing fundamental knowledge and skills (7th ed.). Pearson. Retrieved from https://www.pearson. com/us/higher-education/product/Chiappetta-Science-Instruction-in-the-Middle-and-Secondary-SchoolsDeveloping-Fundamental-Knowledge-and-Skills-7th-Edition/9780137153046.html

Chu, S. K. W., Reynolds, R. B., Tavares, N. J., Notari, M., \& Lee, C. W. Y. (2017). 21st Century skills development through inquiry-based learning. Singapore: Springer Singapore. doi: https://doi.org/10. 1007/978-981-10-2481-8

Cinnirella, F., \& Schueler, R. (2018). Nation building: The role of central spending in education. Explorations in Economic History, 67, 18-39. doi: https://doi.org/10.1016/j.eeh.2017.08.002

Ciolan, L., \& Ciolan, L. E. (2014). Two perspectives, same reality? How authentic is learning for students and 
for their teachers. Procedia - Social and Behavioral Sciences, 142, 24-28. doi: https://doi.org/10.1016/ j.sbspro.2014.07.581

Clark, S., Harbaugh, A. G., \& Seider, S. (2019). Fostering adolescent curiosity through a question brainstorming intervention. Journal of Adolescence, 75, 98-112. doi: https://doi.org/10.1016/j.adolescen ce.2019.07.007

Darling-Hammond, L. (2006). Constructing 21st-century teacher education. Journal of Teacher Education, 57(3), 300-314. doi: https://doi.org/10.1177/0022487105285962

Dobber, M., Zwart, R., Tanis, M., \& van Oers, B. (2017). Literature review: The role of the teacher in inquirybased education. Educational Research Review, 22, 194-214. doi: https://doi.org/10.1016/j.edurev. 2017.09.002

Falloon, G. (2019). Using simulations to teach young students science concepts: An Experiential Learning theoretical analysis. Computers and Education, 135, 138-159. doi: https://doi.org/10.1016/j.compedu. 2019.03.001

FitzGibbon, L., Moll, H., Carboni, J., Lee, R., \& Dehghani, M. (2019). Counterfactual curiosity in preschool children. Journal of Experimental Child Psychology, 183, 146-157. doi: https://doi.org/10.1016/j.jecp. 2018.11.022

Gajardo, F. G., \& Carmenado, I. de los R. (2012). Professional certification for School Principals: Approach of a competence based profile for education quality improvement. Procedia - Social and Behavioral Sciences, 46, 917-925. doi: https://doi.org/10.1016/j.sbspro.2012.05.224

Galeshi, R., \& Bolin, R. M. (2019). The influence of correctional education, skill proficiency, and lifelong learning on social outcomes of incarcerated individuals: Results from PIAAC. The Social Science Journal. doi: https://doi.org/10.1016/j.soscij.2019.09.007

Gerritsen-van Leeuwenkamp, K. J., Joosten-ten Brinke, D., \& Kester, L. (2019). Students' perceptions of assessment quality related to their learning approaches and learning outcomes. Studies in Educational Evaluation, 63, 72-82. doi: https://doi.org/10.1016/j.stueduc.2019.07.005

Gillies, R. M., \& Rafter, M. (2019). Using visual, embodied, and language representations to teach the 5E instructional model of inquiry science. Teaching and Teacher Education, 87. doi: https://doi.org/ 10.1016/j.tate.2019.102951

Greenstein, L. (2012). Assessing 21st century skills: A guide to evaluating mastery and authentic learning. California United State of America: Corwin Press. Retrieved from https://us.corwin.com/en-us/nam/ assessing-21st-century-skills/book237748

Habók, A., \& Nagy, J. (2016). In-service teachers' perceptions of project-based learning. SpringerPlus, 5, 83. doi: https://doi.org/10.1186/s40064-016-1725-4

Hagtvedt, L. P., Dossinger, K., Harrison, S. H., \& Huang, L. (2019). Curiosity made the cat more creative: Specific curiosity as a driver of creativity. Organizational Behavior and Human Decision Processes, 150, 1-13. doi: https://doi.org/10.1016/j.obhdp.2018.10.007

Hamalik, O. (2010). Kurikulum dan pembelajaran. Jakarta: Bumi Aksara. Retrieved from http:/library. um.ac.id/free-contents/index.php/buku/detail/kurikulum-dan-pembelajaran-oemar-hamalik-38275.html

Hammami, S., Saeed, F., Mathkour, H., \& Arafah, M. A. (2019). Continuous improvement of deaf student learning outcomes based on an adaptive learning system and an Academic Advisor Agent. Computers in Human Behavior, 92, 536-546. doi: https://doi.org/10.1016/j.chb.2017.07.006

Huang, C. Q., Han, Z. M., Li, M. X., Jong, M. S. yung, \& Tsai, C. C. (2019). Investigating students' interaction patterns and dynamic learning sentiments in online discussions. Computers and Education, 140. doi: https://doi.org/10.1016/j.compedu.2019.05.015

lucu, R. B., \& Marin, E. (2014). Authentic learning in adult education. Procedia - Social and Behavioral Sciences, 142, 410-415. doi: https://doi.org/10.1016/j.sbspro.2014.07.702

Jamalzadeh, M., \& Shahsavar, Z. (2015). The effects of contextual factors on teacher's beliefs and practices. Procedia - Social and Behavioral Sciences, 192, 166-171. doi: https://doi.org/10.1016/j.sbspro.2015.0 6.024

Jerrim, J., Oliver, M., \& Sims, S. (2019). The relationship between inquiry-based teaching and students' achievement. New evidence from a longitudinal PISA study in England. Learning and Instruction, 61, 35-44. doi: https://doi.org/10.1016/j.learninstruc.2018.12.004

Jiang, Y., Clarke-Midura, J., Keller, B., Baker, R. S., Paquette, L., \& Ocumpaugh, J. (2018). Note-taking and science inquiry in an open-ended learning environment. Contemporary Educational Psychology, 55, 12 29. doi: https://doi.org/10.1016/j.cedpsych.2018.08.004 
Keinänen, M., Ursin, J., \& Nissinen, K. (2018). How to measure students' innovation competences in higher education: Evaluation of an assessment tool in authentic learning environments. Studies in Educational Evaluation, 58, 30-36. doi: https://doi.org/10.1016/j.stueduc.2018.05.007

Kumpulainen, K., \& Rajala, A. (2017). Dialogic teaching and students' discursive identity negotiation in the learning of science. Learning and Instruction, 48, 23-31. doi: https://doi.org/10.1016/j.learninstruc.2016. 05.002

Kyriakides, L., Stylianou, A., \& Eliophotou Menon, M. (2019). The link between educational expenditures and student learning outcomes: Evidence from Cyprus. International Journal of Educational Development, 70. doi: https://doi.org/10.1016/j.jiedudev.2019.102081

Lamnina, M., \& Chase, C. C. (2019). Developing a thirst for knowledge: How uncertainty in the classroom influences curiosity, affect, learning, and transfer. Contemporary Educational Psychology, 59. doi: https://doi.org/10.1016/j.cedpsych.2019.101785

Liao, C. W., Chen, C. H., \& Shih, S. J. (2019). The interactivity of video and collaboration for learning achievement, intrinsic motivation, cognitive load, and behavior patterns in a digital game-based learning environment. Computers and Education, 133, 43-55. doi: https://doi.org/10.1016/j.compedu.2019.01. 013

MacCann, C., Fogarty, G. J., \& Roberts, R. D. (2012). Strategies for success in education: Time management is more important for part-time than full-time community college students. Learning and Individual Differences, 22(5), 618-623. doi: https://doi.org/10.1016/j.lindif.2011.09.015

McNew-Birren, J., \& van den Kieboom, L. A. (2017). Exploring the development of core teaching practices in the context of inquiry-based science instruction: An interpretive case study. Teaching and Teacher Education, 66, 74-87. doi: https://doi.org/10.1016/j.tate.2017.04.001

Min, K. C., Rashid, A. M., \& Nazri, M. I. (2012). Teachers' understanding and practice towards thematic approach in teaching Integrated Living Skills (ILS) in Malaysia. International Journal of Humanities and Social Science, 2(23), 273-281. Retrieved from http://www.ijhssnet.com/journals/Nol_2_No_23_De cember_2012/31.pdf

Mora, H., Signes-Pont, M. T., Fuster-Guilló, A., \& Pertegal-Felices, M. L. (2020). A collaborative working model for enhancing the learning process of science \& engineering students. Computers in Human Behavior, 103, 140-150. doi: https://doi.org/10.1016/j.chb.2019.09.008

Murtonen, M., Gruber, H., \& Lehtinen, E. (2017). The return of behaviourist epistemology: A review of learning outcomes studies. Educational Research Review, 22, 114-128. doi: https://doi.org/10.1016/j.edurev. 2017.08.001

Mussel, P. (2013). Introducing the construct curiosity for predicting job performance. Journal of Organizational Behavior, 34(4), 453-472. doi: https://doi.org/10.1002/job.1809

Pop, M. M., \& Giurgiulescu, M. (2015). The developing of emotional-formative competence of the future teachers, important factor in ensuring the future quality of education. Procedia - Social and Behavioral Sciences, 209, 389-394. doi: https://doi.org/10.1016/j.sbspro.2015.11.209

Purwanto, M. N. (2009). Prinsip-prinsip dan teknik evaluasi pengajaran. Bandung: Remaja Rosdakarya. Retrieved from http://library.um.ac.id/free-contents/index.php/buku/detail/prinsip-prinsip-dan-teknik-eva luasi-pengajaran-m-ngalim-purwanto-26751.html

Rahmaniar, R., Haris, A., \& Martawijaya, M. A. (2015). Kemampuan Merumuskan Hipotesis Fisika Pada Peserta Didik Kelas XMIA SMA Barrang Lompo. Jurnal Pendidikan Fisika, 3(3), 231-240. doi: https:/l doi.org/10.26618/jpf.v3i3.276

Ramdhani, N., Ancok, D., Swasono, Y., \& Suryanto, P. (2012). Teacher quality improvement program: Empowering teachers to increasing a quality of Indonesian's education. Procedia - Social and Behavioral Sciences, 69, 1836-1841. doi: https://doi.org/10.1016/j.sbspro.2012.12.134

Reisner, A., Burns, T. G., Hall, L. B., Jain, S., Weselman, B. C., De Grauw, T. J., ... Chern, J. J. (2017). Quality improvement in concussion care: Influence of guideline-based education. Journal of Pediatrics, 184, 26-31. doi: https://doi.org/10.1016/j.jpeds.2017.01.045

Riduwan. (2009). Dasar-dasar statistika. (P. D. Iswara, Ed.). Bandung: Alfabeta. Retrieved from http://opac. perpusnas.go.id/DetailOpac. .aspx?id=716954

Saariaho, E., Toom, A., Soini, T., Pietarinen, J., \& Pyhältö, K. (2019). Student teachers' and pupils' coregulated learning behaviours in authentic classroom situations in teaching practicums. Teaching and Teacher Education, 85, 92-104. doi: https://doi.org/10.1016/j.tate.2019.06.003

Sabirin, R., Muris, \& Yani, A. (2016). Penerapan pendekatan ilmiah terhadap kemampuan merancang 
percobaan dan hasil belajar fisika peserta didik Kelas X MIA MAN 2 Model Makassar. JPPPF -Jurnal Penelitian \& Pengembangan Pendidikan Fisika, 2(2), 39-46. Retrieved from http://journal.unj.ac.id/ unj/index.php/jpppf/article/view/55/381

Sakaki, M., Yagi, A., \& Murayama, K. (2018). Curiosity in old age: A possible key to achieving adaptive aging. Neuroscience and Biobehavioral Reviews, 88, 106-116. doi: https://doi.org/10.1016/j.neubiorev.2018. 03.007

Sanchez, C. A., \& Weber, K. (2019). Using relevant animations to counter stereotype threat when learning science. Journal of Applied Research in Memory and Cognition, 8(4), 463-470. doi: https://doi.org/10. 1016/j.jarmac.2019.08.003

Shi, M. (2019). The effects of class size and instructional technology on student learning performance. International Journal of Management Education, 17(1), 130-138. doi: https://doi.org/10.1016/j.ijme.20 19.01.004

Şimşek, P., \& Kabapinar, F. (2010). The effects of inquiry-based learning on elementary students' conceptual understanding of matter, scientific process skills and science attitudes. In Procedia - Social and Behavioral Sciences (Vol. 2, pp. 1190-1194). doi: https://doi.org/10.1016/j.sbspro.2010.03.170

Sitorus, J., \& Masrayati. (2016). Students' creative thinking process stages: Implementation of realistic mathematics education. Thinking Skills and Creativity, 22, 111-120. doi: https://doi.org/10.1016/j.tsc. 2016.09.007

Suprihatiningrum, J. (2013). Strategi pembelajaran teori dan aplikasi. Yogyakarta: Ar-Ruzz Media. Retrieved from https://scholar.google.com.ph/citations?user=hvZ-oYcAAAAJ\&hl=en\#d=gs_md_cita-d\&u=\%2Fcita tions\%3Fview_op\%3Dview_citation\%26hl\%3Den\%26user\%3DhvZ-oYcAAAAJ\%26citation_for_view\%3 DhvZ-oYcAAAAJ\%3AL8Ckcad2t8MC\%26tzom\%3D-420

Timostsuk, I., \& Jaanila, S. (2015). Primary teachers' instructional behavior as related to students' engagement in science learning. Procedia - Social and Behavioral Sciences, 197, 1597-1602. doi: https://doi.org/10.1016/j.sbspro.2015.07.117

Tindangen, M. (2018). Inquiry-based learning model to improve higher order thinking skills. Asian Social Science, 14(7), 39-46. doi: https://doi.org/10.5539/ass.v14n7p39

Tissenbaum, M. (2020). I see what you did there! Divergent collaboration and learner transitions from unproductive to productive states in open-ended inquiry. Computers and Education, 145. doi: https://doi.org/10.1016/j.compedu.2019.103739

Trefil, J., \& Hazen, R. M. (2016). The sciences: An integrated approach (8th ed.). John Wiley \& Sons, Inc. Retrieved from https://www. wiley.com/en-us/The+Sciences $\% 3 A+A n+$ Integrated+Approach\%2C+8th+Ed ition-p-9781119049685

Trilling, B., \& Fadel, C. (2009). 21st century skills: Learning for life in our times. San Francisco, CA, US: Jossey-Bass. Retrieved from https://psycnet.apa.org/record/2009-18745-000

Trna, J., Trnova, E., \& Sibor, J. (2012). Implementation of inquiry-based science education in science teacher training. Journal of Educational and Instructional Studies, 2(4), 199-209. Retrieved from http://www .wjeis.org/FileUpload/ds217232/File/23.trna.pdf

Tursinawati. (2015). Analisis kemunculan sikap ilmiah siswa dalam pelaksanaan percobaan pada pembelajaran IPA di SDN Kota Banda Aceh. PIONIR: Jurnal Pendidikan, 4(1), 67-84. Retrieved from https://jurnal.ar-raniry.ac.id/index.php/Pionir/article/view/157/0

Uiterwijk-Luijk, L., Krüger, M., Zijlstra, B., \& Volman, M. (2019). Teachers' role in stimulating students' inquiry habit of mind in primary schools. Teaching and Teacher Education, 86. doi: https://doi.org/10.1016/j. tate.2019.102894

Veloo, A., Perumal, S., \& Vikneswary, R. (2013). Inquiry-based instruction, students' attitudes and teachers' support towards science achievement in rural primary schools. Procedia - Social and Behavioral Sciences, 93, 65-69. doi: https://doi.org/10.1016/j.sbspro.2013.09.153

Wang, H., Sui, Y., Luthans, F., Wang, D., \& Wu, Y. (2014). Impact of authentic leadership on performance: Role of followers' positive psychological capital and relational processes. Journal of Organizational Behavior, 35(1), 5-21. doi: https://doi.org/10.1002/job.1850

Wang, M., Wu, B., Kinshuk, Chen, N. S., \& Spector, J. M. (2013). Connecting problem-solving and knowledge-construction processes in a visualization-based learning environment. Computers and Education, 68, 293-306. doi: https://doi.org/10.1016/j.compedu.2013.05.004

Wang, P.-H., Wu, P.-L., Yu, K.-W., \& Lin, Y.-X. (2015). Influence of implementing inquiry-based instruction on science learning motivation and interest: A perspective of comparison. Procedia - Social and Behavioral 
Sciences, 174, 1292-1299. doi: https://doi.org/10.1016/j.sbspro.2015.01.750

Wheeler, L. B., Maeng, J. L., \& Whitworth, B. A. (2013). Understanding and structuring inquiry: A tale of three teachers. In NARST 2013 Annual International Conference (p. 29). Retrieved from https://pdfs.semantic scholar.org/3b8b/543f3c649c7ec98f3d061b4dedb9bf00b893.pdf?_ga=2.13020019.516094350.1577440 788-396460436.1577440788

Widoyoko, S. E. P. (2013). Evaluasi program pembelajaran: Panduan praktis bagi pendidik dan calon pendidik. Yogyakarta: Pustaka Pelajar. Retrieved from http://library.um.ac.id/free-contents/index.php/ buku/detail/evaluasi-program-pembelajaran-panduan-praktis-bagi-pendidik-dan-calon-pendidik-s-eko-pu tro-widoyoko-45347.html

Yap, W. L., Neo, M., \& Neo, T. K. (2016). The impact of the role of teacher and balance of power in transforming conventional teaching to learner-centered teaching in Malaysian institution of higher education. Pertanika Journal of Social Sciences and Humanities, 24(4), 1849-1868. Retrieved from http://eprints.intimal.edu.my/710/1/The impact of the role of teacher and balance of power in transforming conventional teaching to learner-centered teaching in Malaysian institution of higher education.pdf

Yudarwati, G. A. (2019). Appreciative inquiry for community engagement in Indonesia rural communities. Public Relations Review, 45(4), 1-14. doi: https://doi.org/10.1016/j.pubrev.2019.101833

Yurkofsky, M. M., Blum-Smith, S., \& Brennan, K. (2019). Expanding outcomes: Exploring varied conceptions of teacher learning in an online professional development experience. Teaching and Teacher Education, 82, 1-13. doi: https://doi.org/10.1016/.tate.2019.03.002

Zabit, M. N. M. (2010). Problem-based learning on students' critical thinking skills in teaching business education in Malaysia: A literature review. American Journal of Business Education, 3(6), 19-32. Retrieved from https://files.eric.ed.gov/fulltext/EJ1058610.pdf

Zendler, A., \& Reile, S. (2018). The effect of reciprocal teaching and programmed instruction on learning outcome in computer science education. Studies in Educational Evaluation, 58, 132-144. doi: https://doi.org/10.1016/j.stueduc.2018.05.008 